\title{
10
}

\section{Beckett and unheard sound}

\author{
Catherine Laws
}

\section{The prospect of silence}

Beckett's work has often been perceived as pushing towards its own obliteration, ever closer to the silencing of the voice. His 'characters' - though hardly that - with decaying, almost useless bodies, situated in barren environments, steadily insist that there is nothing to say and no possibility of knowledge or understanding, while (and by) fizzling on with their increasingly broken, empty, repetitive, hopeless - and often very funny - narratives of their very attempts to tell meaningful stories. In the process, the language fragments and fissures even as it pours forth; whether truncated and percussive, or accumulative and spieling, the effect is equally one of impending exhaustion - of the voice on the brink of silence. Furthermore, this notion of a trajectory ever towards, but never quite achieving, a final annihilation of the voice would seem to be validated by the author, who described his writing as 'an unnecessary stain on the silence'. ${ }^{1}$

As Mary Bryden points out, running alongside this is 'an extraordinarily acute attunement to sound: not just to noise, but to intimate, ambient sound'. ${ }^{2}$ An encroaching silence beyond this threatens, oxymoronically, 'to drown all the faint breathings put together'. ${ }^{3}$ Nevertheless, Beckett's work is always alive to the buzzings and hummings of apparently insignificant sound - extraneous environmental noise, but also the clamour of the mind's endless dialogue with itself. This is often a curse or, at best, a false distraction from the painful experience of being, but its silencing is feared as much as it is craved.

The overarching critical narrative of the drive towards silence 
encompasses its own implicit paradoxes; the impossibility of the absolute cessation of the voice, the inaccessibility of silence as an experiential reality, and the simultaneous desiring and fear of that experience, born of uncertainty as to what 'real silence' might mean: death? the void? some other purgatorial form of nothingness? Hélène Baldwin focuses on the Unnamable's incessant revolving of this ambivalent yearning and its inexpressibility: 'that's not the real silence, it says that's not the real silence, what can be said of the real silence, I don't know'. ${ }^{4}$ This dilemma forms a central preoccupation of Beckett's work - in the Trilogy, especially, but also in those other texts of the 1950s and 1960s that recircle the same inaccessible absence, rewording the unsayable: Texts for Nothing is a good example, or Enough. Again, Beckett's own rhetoric, as reported by Charles Juliet, underlines the irony: 'Writing has led me to silence. . .. However, I have to go on'. ${ }^{5}$

The dialectic of inner and outer silence, encompassing the sounds that point to its absence, becomes a marker of the broader interrogation of interiority and exteriority, self and other, being and non-being. However, Beckett doesn't stay entirely trapped within this loop. As his texts twist and turn, the opposition of sound and silence - and especially of voice and silence - starts to come undone. The shadowy, partial figures glimpsed through the torn language of the later work - creatures of ambiguous identity, location, even existence - lie beyond formulations rooted in a linear trajectory, whether towards silence, the void or death. The endpoint always hovers as an absent presence, but is never reached. Instead, there emerges an attempt to articulate an existential 'betweenness' - neither 'there' or ever quite 'not there' - and the approach to sound and the possibility of its absence is part of this.

Silence is usually defined only negatively, as an absence, ${ }^{6}$ and particularly in Western culture specifically as an absence of or abstention from language. Beckett's earlier work appears to rehearse this, with silence mostly conceived in intentional terms only, articulated by and through the cessation of sounds. This entails a vacillation between the positive and negative characteristics of silence as opposed to sound, linked to uncertainty surrounding the distinction between apparently self-produced and external sound: 'Only the words break the silence, all other sounds have ceased. If I were silent I'd hear nothing. But if I were silent 
the other sounds would start again, those to which the words have made me deaf, or which have really ceased. But I am silent, it sometimes happens, no, never, not one second.'7

However, as Carla Locatelli perceives, silence becomes integral to Beckett's radical interrogation of language. His voices move beyond the Western cultural and philosophical positing of silence only as a lack, breaking through 'this farrago of silence and words of silence that is not silence'. ${ }^{8}$ Furthermore, Beckett's texts of the mid-1970s and beyond perform the attempt to find a discourse that can express the difference between silence and 'no sound' as part of the wider destabilising of the coupling of language and representation, suggesting a more complex relationship between sound, silence and the perceiving self. As Locatelli suggests, by attempting an understanding of silence from a perspective other than that of language, 'we can see how the alternative saying/not saying does not necessarily translate into the logocentric dichotomy language/ silence'. ${ }^{9}$

\section{Music and silence in early Beckett}

To my mind, Beckett's later conception of sound and silence is implicit in his earlier notions and uses of music. The critical reading of Beckett's work as a gradual extinguishing of the voice is often accompanied by a related and yet seemingly contradictory one: increasing musicalisation. These two narratives would seem incompatible; how can an impulse towards silence parallel or encompass an aspiration towards a state of music? As an art of sound, music is galvanised and provoked, even threatened and antagonised, by silence. Nevertheless, discussion of Beckett's work often includes reference to an increasing musicality not simply alongside but as part of the drive towards silence. The stutters, sputters, gaps and repetitions that express the impossibilities of language and its prevarications on the threshold of its own ending draw attention to the sounding qualities and patterns of repetition and difference, leaving a sense of meaningfulness without coherence of narrative or connotation.

On one level, this reveals that both music and silence are, ironically, positioned by Beckett as others - sometimes ideal others of sound in general and language in particular. These are fairly typical modernist strategies. Numerous twentieth-century writers 
venerated music's apparent vagueness of meaning yet fullness of expression, perceiving in this a means to rejuvenate tired language. At the same time (and often in the same work), there develops a parallel desire for silence, exposing a dream of obliteration in the face of the post-Freudian crisis of the subject and representation. Beckett is central to Susan Sontag's 1967 depiction of a prevalent 'aesthetics of silence', where the persistence of the myth of art's absoluteness in the face of God's absence leads to 'a craving for the cloud of unknowing beyond knowledge and for the silence beyond speech, so art must tend to anti-art, the elimination of the "subject" (the "object", the "image"), [. . .] and the pursuit of silence'. ${ }^{10}$ However, Beckett's later work both draws on and gradually subverts these oppositions in quite particular ways. In this there might seem something of a parallel with John Cage's rejection of the opposition of music and silence. However, while the two share a sense of the impossibilities of absolute silence these are of a very different kind, and the tensions between sound and its absence are dissimilar in quality. Cage aspires to an almost egoless contemplation and appreciation of sound events as and when they appear, ${ }^{11}$ but this fascinated openness is not replicated in Beckett; the agency, even tyranny, of the listening self is inescapable, and there emerges a focus on the perception, or non-perception, of sound and music as indicative of a state of not-quite-being but not-quite-notbeing in the world.

A brief consideration of some of the shifts in Beckett's use of music, and the relationship to silence, is helpful. As Nicky Losseff and Jenny Doctor point out, music often functions within literature or philosophy as a metaphor for what cannot be said. ${ }^{12}$ While contemporary ('new') musicology has become increasingly concerned with elucidating the contextual and cultural meanings embodied by musical sound and form, and while late twentieth-century linguistics and semiotics emphasise the arbitrariness of linguistic designation, the literary and philosophic conception of music as the 'beyond' of language persists from its nineteenth-century idealist envisioning.

To an extent this is reflected in Beckett's work, with music sometimes idealised as a model for what literature might be or do if freed from the banalities of language, and sometimes providing a refuge from the very struggle with meaning. However, this is not straightforward; music is by no means a singular entity in 
Beckett. It is manifested in different ways: thematised as an 'idea', or a formal and/or expressive model (perhaps most obviously in the early novel Dream of Fair to Middling Women, and in the radio plays Words and Music and Cascando); as actual music in the plays, whether pre-recorded (as in All That Fall, Ghost Trio and Nacht und Träume, for example) or sung by characters (often in the 'old style', as with Winnie in Happy Days); as references to music and musicians (from Pythagoras to vaudeville); and through the musicalising of language effected by attention to qualities of sound and rhythm and increasing use of forms of structural variation and motivic development (a process that becomes more apparent, in different ways and at different levels, in Beckett's writing from the Trilogy on).

Moreover, I will argue that the intertwining of ideas of silence within the evocation of music in the early prose leads to the undoing of the apparent oppositions of language-music and language-silence manifested as linear trajectories. If the impossibility of the coincidence of these processes is never explicitly considered, its attempt engenders Beckett's later, more complex envisioning of the relationship between sound, its perception, and the self.

In the early novel Dream of Fair to Middling Women (completed in 1932), music plays a small but significant role. Beckett's substantial reading and note-taking for Dream included ideas and phrases from La Musique chinoise, by the French musicologist Louis Laloy. ${ }^{13}$ These are not extensive, but are used to articulate ideas about what a novel should (or shouldn't) be or do. Dream selfconsciously grapples with its own development, calling novelistic conventions into question: character, situation, action, causality. In order to explain the recalcitrance of his materials, the narrator draws on the myth of the origins of the Chinese musical scale. If only his characters could act like the twelve different Chinese liŭ and liū sung by the male and female phoenix of the myth, 'we could write a little book that would be purely melodic, think how nice that would be, linear, a lovely Pythagorean chain-chant solo of cause and effect, a one-figured teleophony that would be a pleasure to hear'. ${ }^{14}$

Through the Chinese metaphor (and the consequent, idiosyncratic elaboration of analogies with melodic and harmonic structures, intonation and Pythagorean tuning), ${ }^{15}$ music is presented 
as an idealised model of what this novel might aspire towards but cannot achieve. However, while early narrative interventions imply that the desire for a unified structure of cause and effect persists despite the failure to force the characters into line, later remarks suggest that to produce a rounded novel, with characters conforming neatly to meaningful, complementary roles, would, in the end, be unsatisfactory. Instead, the very obduracy and complexity of these characters develops into an implicit sign of the novel's potential faithfulness to experience.

As this goes on, the protagonist, Belacqua, outlines his own literary ideals: 'The experience of my reader shall be between the phrases, in the silence, communicated by the intervals, not the terms of the statement [...]. I think of Beethofen [sic], [... .] I think of his earlier compositions where into the body of the music he incorporates a punctuation of dehiscence, flottements, the coherence gone to pieces, the continuity bitched to hell'. ${ }^{16}$ This language echoes that earlier in the book, where the narrator bemoans the structural problems caused by the unruliness of his characters. Both employ the idea of music as a model, but while the narrator's depiction of music is of a linear, unified model of cause and effect, Belacqua here evokes a more complex and sophisticated music that he sees as transcending the limits of language and somehow able to reflect the disintegrated nature of experience; one that favours discontinuity, fragmentation, unpredictability - and silence.

This is apparently exemplified by Beethoven (one of Beckett's favourite composers). Belacqua refers to Beethoven's music as an 'incoherent continuum', wherein artistic utterance serves primarily to articulate a position at the edge of a void of meaning, and Beethoven and Rimbaud are artists who 'delimit the reality of insane areas of silence, whose audibilities are no more than punctuation in a statement of silences'. ${ }^{17}$ Beethoven is, in some respects, a strange choice; the idea that his works reject cohesion and unity is hardly credible musicologically, especially today. Beethoven's more fragmentary treatment of often quite simple motives, relative to his predecessors and contemporaries, perhaps explains Beckett's choice, ${ }^{18}$ but the influence of Schopenhauer is also evident. ${ }^{19}$ For Schopenhauer, like Belacqua, Beethoven's music reveals the true chaos of things and suggests the void beyond: 'a true and complete picture of the world, which rolls on in the boundless confusion of innumerable forms, and maintains itself by constant destruction'. ${ }^{20}$ 
Schopenhauer invokes Pythagorean ideas of tuning in his idealist vision of music as both the highest art form and yet revealing of the impossibility of ultimate knowledge, and Beckett's allusions to ideas of melody, harmony and intonation, and specifically to Beethoven's 'dire stroms [sic] of silence', ${ }^{21}$ exhibit a distinctly Schopenhauerian tinge. For Schopenhauer, music becomes the perfect pessimistic symbol, and his identification of Beethoven as the consummate exemplar coincided nicely with Beckett's musical tastes and his own aesthetics of failure.

In Dream, two snippets of musical notation appear in the text, both slight adaptations of a phrase from the first movement of Beethoven's Seventh Symphony. The extract comes from the end of the climax that develops after the exuberant tutti statement of the vivace main theme; it interrupts with a sudden sforzando low $\mathrm{C}$ sharp held by strings alone. Overall, the sense of propulsion is by no means diverted - the interruption is brief - but something of the previous certainty is lost: the apparently unassailable impulsion of the music has for an instant been arrested, its unreflecting momentum called to attention. Through the association of Beethoven with Belacqua's literary aspirations, this musical pause comes to represent Belacqua's attempt to capture the ineffable experience that lies 'between the terms' of language.

Dream, then, does not retain music as an undifferentiated idea, but instead admits different conceptions into play. While the Chinese musical metaphor appears to set music against literature as able to transcend the limits of language, the move towards a more complex view, incorporating silence, destabilises that simple opposition, undoing the reduction of meaning to the 'sayable' and the positioning of music as its sensual and expressive but irrational and meaningless other. Beckett's Beethovenian model here begins to undermine the striving for knowledge and certainty, for art as a means to enlightenment, clarity and understanding, shifting instead towards uncertainty of meaning and identity. The two others of language, music and silence, become entwined in this early attempt to find a form that can 'accommodate the mess' (as Beckett later put it). ${ }^{22}$ In this lies an intimation of Beckett's later language of disintegrated surface and shade-like states of being.

The musical references in Dream form just one part of a network of allusion and quotation that infuses the text at every level. 
Nevertheless, the particular recourse to Beethoven resurfaces. In a letter to his friend Axel Kaun, written in 1937 (a few years after the completion of Dream), Beckett asked:

Is there any reason why that terrible materiality of the word surface should not be capable of being dissolved, like for example the sound surface, torn by enormous pauses, of Beethoven's Seventh Symphony, so that through whole pages we can perceive nothing but a path of sounds suspended in giddy heights, linking unfathomable abysses of silence? ${ }^{23}$

Here, silence is again, paradoxically, intertwined with music as others of language. In some respects, this is unsurprising. For musicians, silence is often a compositionally meaningful presence between phrases or even individual notes, indicative of a meditative pause in the sonic narrative, or forming a communicative point of reference for performers. ${ }^{24}$ Beyond this can lie the conceptual sense of silence as ever-present beneath the musical surface, a backdrop from which sounds emerge and finally disappear; this idea is apparent in a wide range of twentieth-century compositions. ${ }^{25}$ As Jenny Doctor observes, 'in this conception, silence thus shifts from being something that stops action - a silencer, a structural articulator or frame - to being the main canvas'. ${ }^{26}$ In any of these manifestations, however, silence is, as Losseff and Doctor point out, cognitive in its deepest sense, ${ }^{27}$ demanding acknowledgement as an intentional object of perception. Similarly, in Beckett's early positing of Beethoven's ruptured music as a possible model for his own work, but equally in his increasingly musical, fragmented language that apparently keeps the underlying silence at bay, silence is composed in, defined still in terms of the cessation of sound, objectified for cognition, and evoked only by the act of listening for it. In these manifestations, as Sontag says, "Silence" never ceases to imply its opposite and to depend on its presence [. . .]. Silence remains inescapably a form of speech [. . .] and an element in a dialogue. ${ }^{28}$

\section{'that unheeded neither': unheard sound}

In some of Beckett's later texts, however, the picking away at the relationship between sound and silence leads to an alternative proposition: unheard sound. This is apparent in his rather different 
use of Beethoven in the television play Ghost Trio, completed in $1976 .{ }^{29}$ An unidentified male figure inhabits a bare room, awaiting the arrival of a woman who never appears. He holds a tape recorder, and intermittently we hear extracts from the 'Largo' of Beethoven's Piano Trio Opus 70 No. 1 in D minor, nicknamed 'The Ghost'. In each case Beckett specifies the exact passages to be heard, indicating the relevant bar numbers of the score. The drama is one of waiting and listening; a simple, formalised and abstracted visual scene with repetitive sequences of minimal action, contrasted with the evocative but ambiguous expectation of a tryst, articulated by the music. Throughout, the camera, directed by a voice-over from an unidentified woman, interrogates the space and its minimal contents, zooming in and out between three viewing positions as if scrutiny of the scene might reveal its meaning.

The music seems to be used to suggest an idea of elsewhere - or at least of 'not here': the beyond of the room, real or imagined - the space in which the longed-for woman presumably exists. However, Beckett's use of the Beethoven is not that straightforward. The excerpts we hear are not simply Beethoven's 'Largo' played through a tape machine so as to symbolise the absent presence of the woman, drawing on its Romantic spirit for emotional sustenance. The status and origins of the music remain subtly equivocal; it comes and goes, but not always in exact or obvious coincidence with the operation of the tape player. Sometimes it instead seems to be provoked by the camera moving closer to the door, as if symbolising the outside of the room. But not always. Even more subtly, Beckett manipulates the excerpts from the Beethoven, introducing them in an order that could not occur through the ordinary process of listening to a tape recording, and carefully omitting the second subject of the movement - that which would in conventional, old-fashioned musicological terminology be designated female in character. In this way Beckett again undermines the assumed link between the music and the tape recorder, and in so doing suggests a possible trace, however insubstantial, of imaginative agency in the summoning of the music.

Beckett does not simply present a scene of hopeless waiting; a post-human world drained of colour, with music figuring the absent love, controlled by the eye of the viewer moving in and out across the space, searching for meaning. This is apparent on one level, but the uncertainty of the origin, location and status of the 
music, and its recomposed structure offer a counter-balancing; the faintest suggestion that the figure might be using the music to conjure thoughts of the woman. Suddenly, the apparent powers of production in this play are called into question: the figure is no longer necessarily a simple object of scrutiny, mastered by the camera and its controlling voice (and, implicitly, by us as viewers). The 'betweenness' of the music - we cannot be certain if it is 'really' reproduced by the tape player or entirely imagined - articulates the figure's potential resistance to subjection, the possibility of residual creative agency in the face of the technological interrogation of the scene.

The figure in Ghost Trio does not speak. To say that the Beethoven fills his silence, articulating his expectations - standing in for his voice, even - borders on the crass and banal, implying that the music is used in a manner conventional to television and film. However, the visual presence of the source of the music along with its self-conscious invocation but uncertain status transform this notion into something more complex. The ambiguities are such that the Beethoven we hear in Ghost Trio exists in a strange limbo as a perceptual object, neither within nor without either the scene or the figure. In this sense, the figure neither speaks nor is silent; the music is both exterior and interior, heard and yet curiously unheard.

The manuscripts of Ghost Trio reveal that Beckett did not simply select the extracts of the Beethoven to be heard in the play, as one might expect. Instead, he listed a larger number of passages and then decided which should be audible and which should remain 'unheard'. Effectively (and strangely), then, Beckett divided the Beethoven in three: the music that had no role in the play, the music to be heard, and music that stays 'unheard' and even unperceived. ${ }^{30}$ The latter poses a phenomenological and philosophical conundrum in the context of a play: in what sense does it exist - or at least exist differently from the omitted music - if it cannot be heard? While this aspect of Beckett's precompositional thinking is undetectable in the final play, the ambiguities of the production of the music create an implicit counterpart to this third realm beyond the included and excluded music.

More concretely, this instance of unheard sound is not unique: the idea emerges elsewhere, especially in other texts of the mid1970s, often linked to footsteps. The manuscripts show that Beckett vacillated over whether the steps of the Figure in Ghost 
Trio should be audible; it was clearly a significant decision. In the end he made them soundless, whereas, in Footfalls (1975), V describes her daughter's need to hear her own pacing: 'No, Mother, the motion is not enough, I must hear the feet, however faint they fall.' However, when May takes up the story and describes the nights when 'she' paced without pause, there is a moment when the figure vanishes and there is suddenly 'No sound. [Pause.] None at least to be heard. ${ }^{31}$

Beckett spoke to Charles Juliet of the significance of constant pacing to and fro and of counting his footsteps; ${ }^{32}$ these ideas resurface time and again in this period. In the poem 'Roundelay' (1976), steps, and the ability to hear them, seem to act as an indicator of the persistence of perception, even if minimal and ever-fading ('steps sole sound . . . then no sound . . . steps sole sound . . . at end of day'). ${ }^{33}$ As Elizabeth Drew comments, the contrast between existence and non-existence is mediated by that between stasis and movement, ${ }^{34}$ but the oppositions are undermined by uncertainty as to whether presence or absence (of sound, of perception, of the self) is willed or actual.

'écoute-les' (from the Mirlitonnades of 1976-81) demands that we listen to the gradual and difficult accumulation of words, equated with the placing of one foot in front of another ('écoute-les / s'ajouter / les mots / aux mots / sans mots / les pas / aux pas / un à / un'). ${ }^{35}$ However, both Company (1980) and 'pas à pas' (also from the Mirlitonnades) suggest that the taking of steps does not necessarily indicate progression or even location in time or space (one can 'plod on from nought' and end up there too: 'pas à pas / nulle part'), ${ }^{36}$ and that perceiving footfalls is no guarantee of their presence or absence: 'You do not count your steps any more. You do not hear your footfalls any more. Unhearing unseeing you go your way. ${ }^{37}$ As Drew says, 'The journey, which is the active union of space and time, becomes a key to the inner realm where time and space are obliterated'. ${ }^{38}$

This shadowy state of 'betweenness' is expressed in neither (1976). ${ }^{39}$ The sense is of continual wandering to and fro, coming and going between different gradations of shadow, between self and 'unself', achieving stasis only by abandoning such distinctions and even then only in the negative, inexpressible terms of the final words: 'unspeakable home'. Halfway through this short text comes the line, 'unheard footfalls only sound'. The positive presence of 
the sound of steps that nevertheless cannot be heard - or perhaps even the sound of not hearing the footfalls - suggests an undoing of the opposition of sound and silence. The impossible neither of this auditory state, and the concomitant ambiguity of the relationship between the existence of sound and its perception, parallel the ghostly limbo of the text, where some kind of residual agency seems to persist but without the substance of identified self or 'unself'.

In Beckett's later work there emerges a particular focus on the conscious act of listening in and for itself (as opposed to listening to music as an escape from language and the everyday). The image of the listener, usually with head in hand, recurs, often accompanied by vacillation between the idea that things might eventually be 'still' in that 'same soundless place' 40 and the persistent sense, in contrast, that there will 'still' always be stirrings: 'all quite still or try listening to the sounds all quite still head in hand listening for a sound'. ${ }^{41}$ In Sounds (1978), a contrast is set up between straining to hear even the tiniest sounds of a still night ('never quite for nothing even stillest night') and the possibility that complete stillness might allow the listener to let himself be dreamt away to where none at any time [. . . ] where no such thing no more than ghosts make nothing to listen for no such thing as a sound'. ${ }^{42}$ Sounds also lists sounds present by their absence, while in A Piece of Monologue (1977) the idea of sound truly disappearing is posited but immediately corrected: 'Nothing stirring [. . .] Nothing to be heard anywhere. [. . .] No. No such things as none. ${ }^{43}$

Silence, conventionally conceived as non-utterance and nonperception, consequently signifies the obliteration of the self and hence an ultimate state of nothingness, both terrifying and transcendent. In this way silence becomes a force for redemption through its very rejection of meaning: salvation and relief achieved by means of a sonic void. In these late Beckett texts, though, silence is neither produced or banished intentionally; 'no sound' is not necessarily indicative of silence and meaninglessness, and the relationship between the presence of sound and its perception is uncertain. Sound can persist but unheard, stirrings can be still. Both sound and its possible absence seem to be posed as questions, provocations to the still fizzling, unresolved predicament of subjectivity. 
Beckett commented more than once that as he grew older the sense of hearing was becoming more important, ${ }^{44}$ adding 'There is always something to listen to'. ${ }^{45}$ The meaning is unclear though: is it ambient sound to which Beckett refers, or sounds in the head? Juliet describes Beckett sitting still for hours, listening to his 'inner voice', ${ }^{46}$ but even if this is accurate we have no idea what he listened for or heard, and whether actively or passively. Beckett's late texts induce precisely this auditory ambiguity and its ambivalent relationship to consciousness, evoking the sounds and not-quitesounds that balance on the tympanum, between interior and exterior, between moments of significant auditory cognition and the continuous soundings beyond perception.

Simon Critchley argues that silence, the void and meaninglessness are not the goal of Beckett's work, for this would proffer release and salvation, however negative (and as Beckett said, 'Negation is no more possible than affirmation'). ${ }^{47}$ Instead, 'it is a question of meaninglessness becoming an achievement rather than a fact, meaninglessness becoming the work of Beckett's work', and, within this, 'writing is the necessary desacration and desacralization of silence'. ${ }^{48}$ Silence and music might seem to offer salvation from words, but implicit in Beckett's early entwining of ideas of the two lie both the impossibility of stopping speaking and the persistent possibility of finding a means of meaning that does not falsify the transient, contingent, uncertain experience of perception. This entails the unpicking of both music and silence as transcendent, ideal others of language, and the imaginative re-production of sound, music and silence, heard and unheard, as markers of the blurring of interior and exterior, self and unself, being and nonbeing, and of the uncertain, ghostly perseverance of imaginative agency even in the face of death.

In this respect, the apparent persistence of a desire for silence is less significant than the insistent, if shadowy, presence of unheard sound. Beckett seems here to focus not on silence or absent sound but on a kind of leastness of sound; the traces of sound that emerge when listening can come and go (as in Stirrings Still (1983-87), when 'in the end he ceased if not to hear to listen'), ${ }^{49}$ or perhaps an ideal and probably unattainable kind of hearing that is released from the anguish of self-perception. 


\section{Notes}

1 John Gruen, 'Samuel Beckett talks about Beckett', Vogue, 127:2 (February 1970), 108.

2 Mary Bryden, 'Beckett and the sound of silence', in Mary Bryden (ed.), Samuel Beckett and Music (Oxford: Clarendon, 1998), p. 24.

3 Samuel Beckett, The Lost Ones, in The Complete Short Prose 19291989, ed. S. E. Gontarski (New York: Grove, 1995), p. 223.

4 Samuel Beckett, Trilogy (London: Picador, 1979), p. 376. See the discussion in Hélène L. Baldwin, Samuel Beckett's Real Silence (University Park and London: Pennsylvania University Press, 1981), p. 83.

5 Charles Juliet, Conversations with Samuel Beckett and Bram van Velde, trans. Janey Tucker (The Hague: Academic Press Leiden, 1995), p. 141.

6 This is the case with all recent $O E D$ definitions, for example.

7 Samuel Beckett, Texts for Nothing, in The Complete Short Prose 19291989, p. 131.

8 Ibid., p. 125.

9 Carla Locatelli, 'Delogocentering silence: Beckett's ultimate unwording', in Enoch Brater (ed.), The Theatrical Gamut: Notes for a PostBeckettian Stage (Ann Arbor: University of Michigan Press, 2005), p. 70.

10 Susan Sontag, 'The aesthetics of silence', in Styles of Radical Will (New York: Picador, 2002), p. 5.

11 See Cage's comments in Empty Words (London: Marion Boyars, 1980) and Silence (London: Marion Boyars, 1978).

12 Nicky Losseff and Jenny Doctor, 'Introduction', in Nicky Losseff and Jenny Doctor (eds), Silence, Music, Silent Music (Aldershot: Ashgate, 2007), p. 1.

13 This source was discovered by Sean Lawlor, and subsequently incorporated into John Pilling's edition of Beckett's 'Dream' Notebook (Reading: Beckett International Foundation, 1999) and his annotated companion to the novel issued as volume 12 of the Journal of Beckett Studies (2003).

14 Samuel Beckett, Dream of Fair to Middling Women, eds Eoin O'Brien and Edith Fournier (Dublin: Black Cat, 1992), p. 10.

15 A more detailed discussion of ideas of music in Dream, including the significance of Beethoven and the influences of Schopenhauer and Pythagoras alluded to below, forms part of my forthcoming book 'Headaches Among the Overtones': Music in Beckett, Beckett in Music (New York and Amsterdam: Rodopi, 2010).

16 Beckett, Dream of Fair to Middling Women, pp. 137-8.

17 Beckett, Dream, p. 102. 
18 Tia Denora shows that in its own time Beethoven's music was perceived as harmonically adventurous, structurally ambiguous, thickly orchestrated and volatile in dynamic range. Tia Denora, Beethoven and the Construction of Genius (Berkeley, Loss Angeles and London: University of California Press, 1995), p. 129.

19 Beckett's reading of Schopenhauer fed directly into his monograph on Proust (1931), and the influence certainly persisted into the late 1930s; Matthew Feldman comments on the evidence for this in the 'Philosophy Notes'. Traces are less obvious but still present in Dream, including the terms of the musical discussion. In particular, John Wall argues for the influence of Schopenhauer's conception of the relationship between consciousness and the body here (as opposed to the Cartesian dualism more commonly referenced). See Matthew Feldman, Beckett's Books: A Cultural History of Samuel Beckett's 'Interwar Notes' (London: Continuum, 2006), pp. 48-9; John Wall, 'Murphy, Belacqua, Schopenhauer and Descartes: metaphysical reflections on the body', Journal of Beckett Studies, 9:2 (Spring 2000), 21-61. For wider consideration of Schopenhauer's influence on Beckett, see: Terence McQueeny, 'Samuel Beckett as critic of Proust and Joyce' (Ph.D. thesis, University of North Carolina, 1977); J. D. O'Hara, 'Beckett's Schopenhauerian reading of Proust: the will as whirled in re-presentation', in Eric van der Luft (ed.), Schopenhauer: New Essays in Honor of His 200th Birthday (Lewiston, Queenston and Lampeter: The Edwin Mellon Press, 1988), pp. 273-92; Nicholas Zurbrugg, Beckett and Proust (Gerrards Cross: Colin Smythe, 1988).

20 Arthur Schopenhauer, The World as Will and Representation, 2 vols., trans. E. F. J. Payne (New York: Dover, 1969), II, p. 450.

21 Beckett, Dream, p. 139.

22 Beckett quoted in Tom Driver, 'Beckett by the Madeleine', Columbia University Forum, 4:3 (1961), 24.

23 Samuel Beckett, 'German letter of 1937', in Disjecta: Miscellaneous Writings and a Dramatic Fragment, ed. Ruby Cohn (London: John Calder, 1983), p. 172.

24 See Losseff and Doctor, Silence, Music, Silent Music, p. 1.

25 In 'The texture of silence', Jenny Doctor focuses on this idea as exemplified in the music of Webern, drawing also on a range of parallel instances (including Beckett's radio plays). Jenny Doctor, 'The texture of silence', in Losseff and Doctor (eds), Silence, Music, Silent Music, pp. 15-36. In addition, though, it is worth noting that similar conceptions are manifested in music of very different styles; more recently, for example, in the work of composers as diverse as György Kurtág and Arvo Pärt.

26 Doctor, 'The texture of silence', pp. 27-8. 
27 Losseff and Doctor, Silence, Music, Silent Music, p. 1.

28 Sontag, 'The aesthetics of silence', p. 11.

29 Samuel Beckett, Ghost Trio, in Collected Shorter Plays (London: Faber and Faber, 1984), pp. 245-54.

30 For a more detailed discussion of the music in Ghost Trio, see Michael Maier, 'Geistertrio: Beethoven's music in Samuel Beckett's Ghost Trio: part one', in Samuel Beckett Today / Aujourd-hui: Endlessness in the Year 2000, eds Angela Moorjani and Carola Veit, 11 (2001), pp. 267-78; Catherine Laws, 'Beethoven's Haunting of Beckett's Ghost Trio', in Linda Ben-Zvi (ed.), Drawing on Beckett: Portraits, Performances, and Cultural Contexts (Tel Aviv: Assaph, 2003), pp. 197-214.

31 Samuel Beckett, Footfalls, in Collected Shorter Plays, pp. 241-42.

32 Charles Juliet, Conversations, pp. 162 and 163-4.

33 Samuel Beckett, 'Roundelay', in Collected Poems in English and French (New York: Grove, 1977), p. 35.

34 Elizabeth Drew, 'Head to footsteps: "fundamental sounds" in "dread nay" and "Roundelay", in Samuel Beckett Today / Aujourd-hui, eds Angela Moorjani and Carola Veit, 11, pp. 295-6.

35 Samuel Beckett, 'écoute-les', in Collected Poems 1930-1978 (London: John Calder, 1986), p. 71.

36 Samuel Beckett, Company (New York: Grove, 1980), p. 37; 'pas à pas' in Collected Poems 1930-1978, p. 86.

37 Beckett, Company, pp. 36-7.

38 Drew, 'Head to footsteps', 296.

39 Samuel Beckett, neither, in The Complete Short Prose 1929-1989, p. 258.

40 Samuel Beckett, Still 3, in The Complete Short Prose 1929-1989, p. 269.

41 Samuel Beckett, Fizzle 7: Still, in The Complete Short Prose 1929-1989, p. 242.

42 Samuel Beckett, Sounds, in The Complete Short Prose 1929-1989, pp. 267-8.

43 Samuel Beckett, A Piece of Monologue, in Collected Shorter Plays, p. 266.

44 Charles Juliet, Conversations, pp. 147 and 152.

45 Ibid., p. 155.

46 Ibid., p. 152.

47 Ibid., p. 165.

48 Simon Critchley, Very Little . . . Almost Nothing: Death, Philosophy, Literature (London: Routledge, 1997), p. 152.

49 Samuel Beckett, Stirrings Still, in The Complete Short Prose 1929-1989, p. 263. 